\title{
LEXEMES WITH TEMPERATURE CHARACTERISTICS IN THE RUSSIAN LANGUAGE AND IN THE LANGUAGE OF TWI (GHANA): SEMANTIC PECULIARITIES AND USAGE
}

\author{
Abigail L. Etrue \\ State Institute of Russian Language named after A.S. Pushkin, Moscow, Russian Federation
}

\begin{abstract}
The article is devoted to the comparative analysis of the Russian adjectives goryachyy, zharkyy, teplyy, kholodnyy, prokhladnyy and adverbs goryacho, zharko, teplo, kholodno, prokhladno with the lexemes in the Twi language of Ghana that also possess temperature characteristics. Firstly, the basic semantic constituency of the lexical units is described as characteristics of degree and state of heating / coldness of things, items, phenomena; secondly, the metaphoric usage is considered with the aim to denote states, activities, conduct, happenings, time in the Russian and Twi language mentality, and also to depict a person, representing character features and mode of behavior, state of relations with other people and the environment. The author reveals gradation of temperature characteristics of things, items, objects in the Russian language, which is differently conceptualized in the Twi language, in particular, "sharp" temperature transition type from high to low is registered, objects and things are depicted with two main kinds of features - hot and cold. In both languages metaphoric usage of the words under analysis represents many semantic similarities in the way they characterize activities and situations, personal features, in the opposition to evaluation marks; incompatibility is viewed in color depiction (Russian), in description of situations with higher degree of strain (both intellectual and physical) or their opposites (language of Twi).
\end{abstract}

Key words: lexical semantics, metaphorical usage, Russian language, Twi language, temperature.

УДК 811.161.1/811.72’373

ББК 81.053

Дата поступления статьи: 26.09.2016

Дата принятия статьи: 28.10.2016

\section{ЛЕКСЕМЫ, ОБОЗНАЧАЮЩИЕ ТЕМПЕРАТУРНЫЕ ПРИЗНАКИ В РУССКОМ ЯЗЫКЕ И В ЯЗЫКЕ ТЬВИ (ГАНА): ОСОБЕННОСТИ СЕМАНТИКИ И УПОТРЕБЛЕНИЯ}

\author{
Абигель Линда Этру \\ Государственный институт русского языка им. А.С. Пушкина, г. Москва, Российская Федерация
}

\begin{abstract}
Аннотация. Статья посвящена анализу прилагательных горячий, жаркий, тепльй, холодныци, прохладный и наречий горячо, жарко, тепло, холодно, прохладно в сопоставлении с лексемами языка тьви (Гана), содержащими признак 'температура', с целью выявить их специфику в русском лингвоментальном пространстве и в лингвоментальном пространстве носителей языка тьви. Эти единицы рассмотрены, вопервых, в аспекте их лексического значения: показано, как характеризуются степени и состояния нагретости 6 / холодности веществ, предметов, явлений и их градации; во-вторых, в аспекте их относительного (метафори후 ческого) употребления для описания состояний действий, времени, а также человека, черт его характера, поведения, отношений с другими людьми и с действительностью. Установлено, что в русском языке представлена градация температурных признаков предметов, веществ, тел, а в языке тьви отражен «резкий переخ ход» от высокой температуры к низкой: предметы обладают только двумя основными признаками - горячий и холодный. В метафорическом употреблении лексических единиц в русском языке и в языке тьви сходства (?) проявляются в характеристике действий и ситуаций, черт человека, в полюсе их оценки; различия касаются
\end{abstract}


возможности выражать специфику цвета (русский язык), обозначать ситуации, требующие большого напряжения (умственного или физического) или противоположные им (язык тьви).

Ключевые слова: лексическая семантика, метафорическое употребление, русский язык, язык тьви, температура.

1

В последние десятилетия лингвисты уделяют много внимания изучению национальнокультурной специфики различных языков, в том числе и на лексическом материале. По мнению Н.Л. Шамне, существует два аспекта рассмотрения национально-культурной специфики семантики лексических единиц. Первый аспект связан с выявлением национально-специфической семемы (семем) в семантической структуре слова. Эта семема безэквивалентна, хотя может иметь некоторые переводные соответствия. Второй аспект связан с выявлением национальных компонентов в структуре значений лексических единиц. Эти несовпадающие компоненты значений обнаруживаются при анализе векторных соответствий, при словарном рассмотрении единицы [2, с. 173].

Наше исследование отражает второй аспект в изучении национально-культурной специфики лексических единиц и проводится с учетом классификации компонентов значения слова, которую предложил И.А. Стернин. Как утверждает ученый, разные макрокомпоненты значения отвечают за разные виды национальной специфики семантики. Национально-культурная специфика, обнаруживаясь в случаях полной (мотивированной) безэквивалентности или отсутствия / наличия определенных компонентов значения, обусловленного отсутствием / наличием соответствующих признаков в называемых словом объектах материальной и духовной культуры, сосредоточена в денотативном и эмпирическом компонентах значения; национально-концептуальная специфика, выявляемая в случае немотивированных лакун и в межъязыковых родовидовых несовпадениях, содержится в денотативном компоненте; национально-оценочная и национально-эмоциональная - в коннотативном; национально-языковая специфика, отражающая различия между единицами двух языков, связанные с исторически сложившейся системой языков и не связанные с культу- рой или особенностями мышления народа, представлена в структурном макрокомпоненте значения [1].

Выявление национальной специфики двух разных языков на уровне лексики и понятийного содержания может осуществляться, в частности, путем сопоставления словарных материалов. При таком сопоставлении можно наблюдать несовпадения понятийных центров при тождественной отнесенности к идентичному отрезку реальной действительности.

\section{2}

Слово температура происходит от лат. temperature - 'правильное соотношение, нормальное состояние, надлежащее смешение, соразмерность'. В разных толковых словарях русского языка температура определяется как: 'степень нагретости / холодности какоголибо тела, вещества'; 'степень теплоты человеческого тела, как показатель состояния здоровья'; 'число градусов, зафиксированное в определенном месте в определенное время'; 'величина, характеризующая тепловое состояние чего-либо'; ‘степень теплоты тела, выше нормальной'; 'жар' и пр. (см., например: Даль, MAC). При описании степени нагретости / холодности каких-либо веществ и предметов употребляются следующие лексические единицы (прилагательные): горячий, жаркий, тепльй, холодный, прохладный, а при описании состояний нагретости / холодности соотносимые с ними наречия: горячо, жарко, тепло, холодно, прохладно. Эти лексические единицы не только номинируют степень и состояния, но и отражают их градацию.

Горячий - 'имеющий высокую температуру, сильно нагретый, очень теплый, огненный, излучающий жар': горячая вода, горячий чайник, горячий утюг, горячая пища, горячие руки. О погоде говорят, используя метафоры, например: горячее солние (в значении жаркое). Горячее может выступать в качестве субстантивированного прилагатель- 
ного в значении 'основное блюдо (суп)': Мне, пожалуйста, горячее.

Жаркий - 'источающий, дающий сильный жар, палящий, горячий, знойный':жсаркое солнце, жаркие лучи, жаркий огонь, знойный день (очень жаркий), жаркое лето, жаркие месяиы, жаркий климат, жаркие страны. Жаркий также обозначает 'сильно нагретый, натопленный (о помещении)'.

Tenлый - 'дающий, источающий тепло'. Обозначает 'слегка нагретый': теплый чай, теплая ванна, теплый дождь; 'не холодный': теплая погода, теплая весна, тепльй день; 'высокая среднегодовая температура воздуха в стране, местности': теплье страны; 'хорошо защищающие от холода вещи': теплые носки, теплое одеяло, теплье одежды; 'отапливаемый, утепленный (о помещении)': теплая квартира, теплье уютные дома, теплый коридор, теплая веранда.

Прохладный - 'умеренно холодный, не жаркий, освежающий, дающий приятную прохладу': прохладная погода, прохладное лето.

Холодный - 'имеющий низкую или относительно низкую температуру': холодная вода, холодный ветер, холодный день, холодная рука, холодная погода, холодное лето, холодное место и др.;"не отапливаемый, не утепленный, плохо держащий тепло, плохо защищающий от холода, дающий мало тепла': холодная дача, холодный подвал, холодный сарай, холодная шинель, холодное одеяло; 'утративший теплоту, остывший, недостаточно горячий, приготовляемый или подаваемый в охлажденном виде': холодный чай, холодная вода, холодные завтраки, холодная закуска.

Наречия горячо, жарко, тепло, холодно, прохладно употребляются в следующих значениях: а) присутствие жары, тепла, холода, прохлады где-либо (место, помещение): на улице холодно, в комнате жарко, в избе прохладно, сегодня тепло во дворе; б) ощущение, вызывающее у кого-либо при контакте с предметом, телом, содержащим или источающим жар, холод, чувство теплоты, прохлады: мне горячо, пусть остынет, мне жарко, мне холодно, ему прохладно.

Анализируемые лексические единицы представлены в относительном (метафорическом) употреблении при описании:
- состояния действий, поступков, случаев, времени - 'очень сильный, интенсивный, напряженный, усердный, трудный, спешный, требующий сосредоточения всех сил': горячая работа, горячий разговор, горячий бой, горячая пора, горячее время, горячие дни, жаркая схватка, жаркая перестрелка, жаркая битва; 'очень оживленный, бурный, неутомимый, ревностный': жаркий спор.

- качеств, черт характера человека 'страстный, пылкий', 'неуравновешенный, несдержанный, запальчивый, вспыльчивый’ : горячая голова, горячее сердие, горячая кровь, жаркое сердие, жаркий поборник, горячий человек, горячий поклонник, жаркий почелуй;

- действий, отношений, поступков, отличающихся внутренней теплотой, лаской, сердечностью: горячий привет, теплая встреча, теплое письмо, теплье слова, теплый тон, теплое слово, теплый взгляд, теплая компания (веселая, приветливая); или основанных на доводах рассудка: холодное решение, холодная сосредоточенность;

- эмоций, чувств, желаний, отличающихся глубокой, сильной выраженностью: горячая любовь, горячее желание, горячее стремление; проникнутых добрым, любовным чувством по отношению к кому-либо: теплая признательность, теплое сочувствие, теплое отночение, теплое доверие;

- состояний, действий, лишенных душевной теплоты, чувства страстности, а также качеств человека (суровый, строгий, рассудочный, равнодушный, безразличный, не проявляющий интереса к кому-, чему-либо, хладнокровный, крайне сдержанный в проявлении чувств): холодное сердие, холодный темперамент, холодный прием, холодный ответ, холодный взгляд, холодная встреча, прохладная встреча, прохладные отношения;

- цвета и света: яркого, огненного, красно-желтого, оранжевого, блестящих предметов: жаркая позолота; неяркого: холодный свет. В МАС зафиксировано прилагательное холодный в устаревшем метафорическом значении 'человек, работающий с простейшими приспособлениями, инструментами, примитивным способом (обычно о сапожнике, парикмахере)': Холодный сапожник у наших 


\section{МАТЕРИАЛЫ И СООБЩЕНИЯ}

ворот дырявую обувь в починку берет (Михалков. Холодный сапожник).

По данным БФС, исследуемые лексемы входят в состав фразеологизмов, например: всыпать горячих (жестоко выпороть когонибудь); по горячим следам (сразу, незамедлительно, тотчас после какого-либо события): раскрыть преступление по горячим следам; ловить, искать по горячим следам; горячая линия (постоянно работающая, экстренная связь); под горячую руку (когда кто-то в плохом настроении, раздражен, обозлен), подвернуться / попасть под горячую руку (не вовремя, неудачно встретиться с разъяренным чем-либо человеком и получить от него нагоняй, взбучку, упрек); холодная война (конфликт, при котором стороны не прибегают к открытому противостоянию); холодное оружие (копья, мечи, шашки, сабли, ножи, то есть то, которое используется при помощи мускульной силы человека при непосредственном контакте с объектом поражения).

\section{3}

Рассмотрим лексические единицы, отражающие представления о температуре в языке тьви. Для обозначения понятия «температура» в этом языке нет специальной лексемы, оно обозначается сочетанием пwипи ne hye [ньюну не ше], то есть 'холод и жара'. В его состав входят слова пwипи [ньюну] 'имеющий низкую температуру, охлажденный, замороженный (холодный)' и hye [ше] 'имеющий высокую температуру, нагретый, дающий жар (горячий и жаркий)'. Эти единицы, а также слово $d w o$ [джо] - 'остывший, недостаточно горячий, умеренно холодный, освежающий, дающий приятную прохладу (теплый, прохладный)', употребляются как и их эквиваленты в русском языке. Отметим, что в языке тьви эти слова могут выполнять функции и прилагательных, и существительных, и наречий. Однако в Гане меняются не времена года, а сезоны, поэтому нет необходимости передавать, например, такие значения, как холодная зима, жаркое лето, отсутствует также понятие «теплая одежда» и слова, номинирующие градус, градусник, следовательно, нет и выражения сколько градусов.
Для обозначения холода, жары, прохлады где-либо, их ощущений у кого-либо в языке тьви используются существительные aws [аво] - 'холод', shyew [ошиу] - 'жара': aws ws absnten - 'на улице холод', shyew ws abonten - 'на улице есть жара', aws de me 'я чувствую холод', shyew de me - 'я чувствую жару', aws ws ти - 'холодно', shyew wə mu - 'жарко'. Слово $d w o$ для характеристики погоды не употребляется.

В тьви слова hye, nwunu, dwo употребляются в тех же метафорических значениях, что и русские лексемы, обозначающие разную температуру. Однако, в отличие от русского языка, в тьви представлены значения 'тяжелый, требующий физической мужской силы (о работе или действии)': edwuma hye; 'важный, серьезный, требующий глубокого размышления, незамедлительного решения, решения на уровне начальства (о проблеме, деле и пр.)': ascm a ano ye hye; 'легкий, простой, ненапряженный, несерьезный, легко решающийся': ascm a ano dwo, edwuma a ano $d w o$; 'опасный, рискованный (о каком-либо бизнесе, деле, сделке)': edwuma a ano yє hye; 'безопасный': edwuma a ano dwo; 'занятый, действующий под давлением': aso hye (букв. горячие уши).

Лексические единицы со значением температуры входят в состав идиом (их эквиваленты отсутствуют в русском языке), называющих свойства человека, черты его характера, например, смелость, храбрость: eniso hye (букв. горячие глаза); умный: adwen mu hye (букв. горячий внутри мозгов); талантливый: nsa ano hye (букв. горячие руки); быстрый, активный: ho hye (букв. горячеe тело); агрессивный: eniso hye (букв. горячие глаза); спокойный, миролюбивый, вежливый, терпеливый: aho dwo (букв. теплое тело); ярость, гнев: ebufu hye (букв. горячий рост грудных волос); некрасивый, непривлекательный, нечистоплотный: aho пwипи (букв. холодное тело). Безэквивалентные идиомы используются для обозначения состояния человека, которому тяжело найти выход из какой-либо трудной ситуации, положения: n'aso aye hye (букв. уши стали горячие), а также для обозначения трудного времени, трудных времен, трудного момента, трудных моментов, смутного времени, смутных времен: bre a ети ує 
hye / ттге а ети ує hye (букв. горячее время / горячие времена ) - ср. антонимичные им bre a ети dwo / mmre a ети dwo (букв. теплое время / теплые времена); попадания в неприятную ситуацию: tonsuo hye ти (букв. падать / упасть в горячую воду); состояния загруженности многими делами: $y \varepsilon$ hye (букв. быть / стать горячим).

\section{4}

Итак, в русском языке представления о высокой температуре эксплицируются двумя прилагательными - горячий и жаркий, а в языке тьви одним - hye. Разную температуру в русском языке обозначают наречия, а в языке тьви в функции наречий выступают формы существительных. В русском языке лексические единицы отражают градацию температурных признаков предметов, веществ, тел, а в языке тьви - «резкий переход» от высокой температуры к низкой: вещи, предметы и пр. обладают только двумя основными признаками, что отражено в семантике лексем: hye - 'горячий (имеющий высокую температуру)' и shyew - 'жара'; nwипи - 'холодный (имеющий низкую температуру)' и aws'холод', а $d w o$ находится за пределами этих двух признаков.

В метафорическом употреблении рассмотренных лексических единиц в русском языке и в языке тьви обнаруживаются сходства в характеристике действий и ситуаций, черт человека. Кроме того, жаркий, теплый, $h y e, d w o$ выражают положительную оценку действий, отношений между людьми, а холодный, прохладный, пжипи - отрицательную. При этом и в русском языке, и в тьви слова с семантикой температуры могут использоваться в специфических значениях, различающих данные языки.

\section{СПИСОК ЛИТЕРАТУРЫ}

1. Стернин, И. А. О выявлении национальнокультурной специфики семантики слова / И. А. Стернин // Национальное и интернациональное в развитии языков. - Иваново : УНИВЕРСИТЕТЬ, 1984. C. 3-10.
2. Шамне, Н. Л. Актуальные проблемы межкультурной коммуникации / Н. Л. Шамне. - Волгоград : Изд-во ВолГУ, 1999. - 206 с.

\section{СЛОВАРИ}

БФС-Антонова, Л. В. Большой фразеологический словарь русского языка / Л. В. Антонова. М. : Дом Славянской книги, 2013. - 928 с.

Даль - Даль, В. И. Толковый словарь живого великорусского языка : в 4 т. / В. И. Даль. - 3-е изд. М. ; СПб. : Изд-во Тип. М.О. Вольфа, 1880-1882. T. 1-3.

$M A C$ - Словарь русского языка : в 4 т. / под ред. А. П. Евгеньевой. - 2-е изд., испр. и доп. - М. : Русский язык, 1981-1984.

Christaller, J. G. Dictionary of the Asante and Fante Language called Tshi (Twi) / J. G. Christaller. 2nd. ed. - Basel : BASEL Evangelical Missionary Society, 1933. $-607 \mathrm{c}$.

\section{REFERENCES}

1. Sternin I.A. O vyyavlenii natsionalno-kulturnoy spetsifiki semantiki slova [On Revealing National and Cultural Peculiarities of Word Semantics]. Natsionalnoe i internatsionalnoe v razvitii yazykov [The National and the International in the Development of Languages]. Ivanovo, UNIVERSITET Publ., 1984. pp. 3-10.

2. Shamne N.L. Aktualnye problemy mezhkulturnoy kommunikatsii [Relevant Problems of Inter-Cultural Communication]. Volgograd, Izd-vo VolGU, 1999. 206 p.

\section{DICTIONARIES}

Antonova L.V. Bolshoy frazeologicheskiy slovar russkogo yazyka [Large Phrasebook of the Russian Language]. Moscow, Dom Slavyanskoy knigi Publ., 2013. 928 p.

Dal V.I. Tolkovyy slovar zhivogo velikorusskogo yazyka: $v 4 t$. [Explanatory Dictionary of the Living Great Russian Language. In 4 vols]. Moscow; Saint Petersburg, Izd-vo Tip. M.O.Volfa, 1880-1882.

Evgenyeva A.P., ed. Slovar russkogo yazyka: v $4 t$. [The Dictionary of the Russian Language]. Moscow, Russkiy yazyk Publ., 1981-1984.

Christaller J.G. Dictionary of the Asante and Fante Language called Tshi (Twi). 2nd ed. Basel, BASEL Evangelical Missionary Society, 1933. 607 p. 


\section{МАТЕРИАЛЫ И СООБЩЕНИЯ}

\section{Information About the Author}

Abigail L. Etrue, Postgraduate Student, Department of Russian Literature and Intercultural Communication, State Institute of Russian Language named after A.S. Pushkin, Akademika Volgina St., 6, 117485 Moscow, Russian Federation, ahwedieabena@gmail.com.

\section{Информация об авторе}

Абигель Линда Этру, аспирант кафедры русской словесности и межкультурной коммуникации, Государственный институт русского языка им. А.С. Пушкина, ул. Академика Волгина, 6, 117485 г. Москва, Российская Федерация, ahwedieabena@gmail.com. 